\title{
Do ectoparasites determine cleaner fish abundance? Evidence on two spatial scales
}

\author{
Karen L. Cheney, Isabelle M. Côté* \\ Centre for Ecology, Evolution and Conservation, School of Biological Sciences, University of East Anglia, \\ Norwich NR4 7TJ, UK
}

\begin{abstract}
Cleaner fish on coral reefs can have a significant impact on the diversity and distribution of their fish clients. Understanding the factors affecting the distribution of cleaners themselves therefore becomes an important consideration for elucidating the mechanisms controlling coral reef fish community structure. We hypothesised that obligate cleaner fish, which rely almost exclusively on ectoparasites gleaned from clients, should be more abundant in areas rich in their preferred prey, namely parasitic gnathiid isopod larvae. We tested predictions from this hypothesis on 2 spatial scales in the Caribbean: among reefs within Barbados, and among 6 islands spanning the Greater and Lesser Antilles. As predicted, densities of coral-dwelling cleaning gobies Elacatinus spp., which are active cleaners, were higher in areas of high rates of emergence of gnathiid larvae from the benthos. This relationship was not observed in sponge-dwelling cleaning gobies, which rely mainly on nonclient-gleaned food sources. The density of coral-dwelling cleaners was also correlated with client density, but contrary to our prediction was not related to ectoparasite loads of a common reef fish client. Cleaning goby abundance is more likely to be a consequence than a cause of ectoparasite availability, since cleaning goby recruitment is usually linked to factors related to foraging, and territorial clients do not preferentially settle near cleaning gobies. Whether the link between cleaner abundance and ectoparasite availability is mediated through differential recruitment or differential survival of cleaners in parasite-rich and parasite-poor areas remains to be determined.
\end{abstract}

KEY WORDS: Cleaning symbiosis · Reef fish community structure - Gobiosoma spp. Resale or republication not permitted without written consent of the publisher

\section{INTRODUCTION}

Cleaning interactions among fish are ubiquitous in the marine environment, and involve the removal of ectoparasites by small cleaner fish from the surface of client fish (see Côté 2000 for review). Obligate cleaning species, i.e. those that derive most of their energetic requirements from cleaning, can remove a large number of ectoparasites daily. The cleaner wrasse Labroides dimidiatus, for example, can ingest up to 1200 larval gnathiid ectoparasites from clients every day (Grutter 1996). Conversely, individual clients can visit a cleaning station up to 144 times $\mathrm{d}^{-1}$ (Grutter 1995b). The interactions between cleaner fish and their clients can therefore have significant impacts on the daily activities of client reef fish, and pos- sibly impact demographics of ectoparasite populations (Grutter 2002).

Cleaner fish have been shown to reduce significantly ectoparasite numbers on individual clients (Grutter 1999, Cheney \& Côté 2001, Grutter \& Lester 2002). The importance of this reduction in ectoparasite loads is not clear. Although it does not affect reproductive parameters in Caribbean damselfish (Cheney \& Côté in press), it could nevertheless prevent parasite infestation from reaching levels at which pathological effects occur (Grutter 2002), reduce the likelihood of diseases spread by ectoparasitic vectors (Honma \& Chiba 1991, Davies et al. 1994), and thus decrease mortality (Paperna \& Por 1977). Given these potential impacts on clients, and the fact that client visits to cleaning stations are often constrained by travel costs (Cheney \& 
Côté 2001), the distribution of reef fish clients should be affected by the presence of cleaning stations. However, there is mixed support for this prediction. Higher territorial densities of the Caribbean longfin damselfish Stegastes diencaeus were not observed around cleaning goby Elacatinus spp. stations (Whiteman et al. 2002), and experimentally vacated longfin damselfish territories near cleaning stations were not colonised faster than territories further away from cleaners, which would have been expected if proximity to cleaners was important to damselfish (Cheney \& Côté 2003). Moreover, other species of damselfish that also visit cleaning gobies were distributed randomly with respect to cleaning stations (Whiteman et al. 2002). By contrast, at larger inter-reef scales, there are marked reductions in the diversity of non-territorial clients when cleaner wrasses are removed from reefs, and increases when cleaners are added (Bshary 2003, Grutter et al. 2003).

If cleaning organisms have a significant impact on the diversity and distribution of their clients, then understanding the factors affecting the distribution of cleaning organisms themselves becomes an important consideration. The distribution of cleaners has been shown to vary both between (Arnal et al. 1999) and within reefs (Sikkel et al. 2000). Arnal et al. (1999) demonstrated that cleaner wrasse density on 3 South Pacific reefs was correlated with fish densities, species richness, and biomass across reefs. On a smaller scale, Sikkel et al. (2000) found that the density of cleaning gobies was higher at the seaward edge of a Barbadian fringing reef, and client density is also greater in this area (K. L. Cheney unpubl. data). From these studies, however, it is not clear whether cleaner fish cause or respond to the distribution of their clients.

Strong relationships exist between habitat characteristics and reef fish distribution for species with specific dietary requirements. Corallivorous butterflyfish, for example, are invariably associated with areas of high live coral cover, and areas with relatively more live coral support greater densities of butterflyfishes (Cadoret et al. 1995, Khalaf \& Kochzius 2002). We therefore hypothesised that obligate cleaner fish should show similarly strong associations with areas rich in their preferred prey, namely parasitic gnathiid isopod larvae (Grutter 1997, Arnal \& Côté 2000). High cleaner fish densities should therefore be observed in (1) areas where the rate of emergence of gnathiid larvae from the benthos is high - although gnathiids are occasionally found in plankton tows (e.g. Jacoby \& Greenwood 1988), it is generally believed that they do not travel far from their point of emergence before colonising a fish host, (2) areas where fish client density is high, (3) areas where both fish client density and mean client ectoparasite loads are high, and (4) habitat types associated with high parasite emergence rates, high intensities of ectoparasites on clients and high client densities.

In this paper, we tested these predictions with 2 species of Caribbean cleaning gobies (Elacatinus prochilos and E. evelynae) on 2 spatial scales by relating cleaning goby densities to ectoparasite availability, client density, and habitat features on an island-wide scale and among reefs across 6 Caribbean islands. The propensity to clean of E. prochilos, in particular, and E. evelynae to a lesser extent, is closely linked to the substratum upon which these fish live. Cleaning gobies that have settled on coral usually live in monogamous pairs and clean actively, whereas those established on sponges (Xestospongia muta) live in large groups of up to 40 individuals and forage mainly on polychaete worms living within sponge tissues (Whiteman \& Côté 2002). Coral-dwelling gobies should therefore be more likely to exhibit relationships with ectoparasite distribution and availability than spongedwelling gobies, which clean very little.

\section{MATERIALS AND METHODS}

Study sites and species. The intra-island study was conducted on 5 fringing reefs situated on the west coast of Barbados, West Indies, between February and May 2001. We surveyed 3 reefs situated in the Barbados Marine Reserve (Vauxhall, North and South Bellairs) and 2 reefs situated $7 \mathrm{~km}$ north of the reserve (Greensleeves and Tropicana). These reefs are relatively degraded and predominantly covered in turf algae, which are grazed by herbivores such as damselfish (Pomacentridae), parrotfish (Scaridae) and surgeonfish (Acanthuridae).

For the comparison between islands, we obtained data from 3 reefs on each of 6 Caribbean islands: Barbados, Curaçao, Tobago, Puerto Rico, St John (US Virgin Islands) and Grenada. All data were collected from February to June 2002. Reef characteristics varied among islands, but most reefs were relatively degraded, with low coral cover and abundant herbivorous fish grazing the turf algal cover.

In Curaçao, the study sites were fringing reefs at depths of 5 to $15 \mathrm{~m}$ near the Caribbean Marine Biological Foundation (CARMABI) Institute. Coral diversity and hard coral cover (19 to $35 \%$ ) were relatively higher than at other islands, as was fish density (K. L. Cheney pers. obs.). In Tobago, 3 fringing reefs situated at Store, Arnos Vale and Culloden bays were studied (depths: 3 to $10 \mathrm{~m}$ ). Coral cover ( 26 to $52 \%$ ) was relatively high, and fish numbers were high. In Grenada, we studied Molinere Point, Happy Hill and Boss reefs, which had abundant macroalgal cover and relatively low fish density. In Barbados, the 3 reefs studied were North Bellairs, Vauxhall 
and Tropicana, which were also part of the intra-island study. In Puerto Rico, the 3 study sites were shallow (2 to $5 \mathrm{~m}$ ) outer reefs off Isla Magueyes Marine Laboratory, with low hard-coral cover (11 to $15 \%$ ) and high soft-coral cover (32 to $53 \%$ ), and a relatively large number of fish. In St John, US Virgin Islands, due to time constraints, only 1 shallow fringing reef site was studied in Lameshur Bay (depth: 1 to $4 \mathrm{~m}$ ), with low fish numbers and low coral cover (9 to $16 \%$ ).

Sharknose cleaning gobies Elacatinus evelynae and broadstripe cleaning gobies $E$. prochilos were the most abundant obligate cleaners on the reefs studied. These cleaning gobies are small (max. $4.5 \mathrm{~cm}$ total length [TL]) and conspicuously marked with yellow, white or bluish stripes running laterally from snout to caudal peduncle on a black body.

Cleaner and client fish densities. We quantified client and cleaner fish densities by running 5 to 6 randomly placed $20 \mathrm{~m}$-long transects parallel to the shore on each reef. After a delay of $2 \mathrm{~min}$, to allow any disturbance caused when laying the transect chain to subside, one SCUBA diver (K. L. Cheney) swam along the transect at a constant speed, looking forward and approximately $1.5 \mathrm{~m}$ up from the reef, counting the number of longfin damselfish Stegastes diencaeus, yellowtail damselfish Microspathodon chrysurus, brown chromis Chromis multilineata, yellow goatfish Mulloidichthys martinicus, smallmouth grunt Haemulon chrysargyreum and French grunt Haemulon flavolineatum within $1 \mathrm{~m}$ on either side of the transect. These species are the most frequent visitors to cleaning goby stations (K. L. Cheney pers. obs.). The diver then swam along the transect a second time to count the number of cleaning gobies, carefully searching the area within $1 \mathrm{~m}$ on either side of the chain. We noted the cleaning goby species and substratum (coral, rock or sponge) on which each goby was found. We recorded separately, based on a visual assessment of cleaning goby TL, the number of adults ( $>24 \mathrm{~mm}$ ), sub-adults (18 to $24 \mathrm{~mm}$ ) and juveniles $(<18 \mathrm{~mm})$. Fish densities were expressed as the number of individuals recorded per $40 \mathrm{~m}^{2}$.

Gnathiid isopod larval emergence rates. We placed 3 to 5 traps on 4 reefs in Barbados (South Bellairs, North Bellairs, Vauxhall and Tropicana reefs), and on each of the reefs studied on each island. Emergence traps consisted of a $200 \mu \mathrm{m}$ nylon mesh in a pyramidal shape attached to a $1 \mathrm{~m}^{2}$ frame made of polyvinyl chloride (PVC) pipe filled with lead weights. A $750 \mathrm{ml}$ plastic bottle was attached to the cod end of the mesh, $1 \mathrm{~m}$ above the bottom. A small amount of air placed in the bottle provided positive buoyancy. Nets were cleaned and moved to a new location on the study reef each day. The nets were deployed and collected at the same time the following day, constituting a $24 \mathrm{~h}$ sampling schedule. Sampling consisted of 4 to $5 \mathrm{~d}$ on each reef.
Client ectoparasite load assessment. We assessed ectoparasite loads on 1 species of client only, i.e. the longfin damselfish, in part because of time constraints and in part because the relationship between longfin damselfish and cleaning gobies is particularly well understood (Cheney \& Côté 2001, in press). Longfin damselfish are medium-sized ( $\mathrm{TL} \approx 80$ to $100 \mathrm{~mm}$ ) and defend mutually exclusive feeding territories of ca. $1 \mathrm{~m}^{2}$. Longfin damselfish are aggressive towards other common facultative cleaners such as juvenile bluehead wrasse Thalassoma bifasciatum, juvenile angelfish Pomacanthus spp. and Spanish hogfish Bodianus rufus. Hence, cleaning gobies represent their main fish cleaners. In Barbados, at least, the ectoparasite load of longfin damselfish is not significantly different from that of other common client species considered in this study (Molloy \& Côté 2003), and may thus be considered as a local index of overall ectoparasite load.

We removed haphazardly 5 to 8 longfin damselfish from each reef in the study. The only exception was in Grenada, where the number of longfin damselfish was so low $(<1$ ind. per $200 \mathrm{~m}$ ) that our collection could have had an impact on the population. No damselfish were therefore collected from Grenada. Damselfish were collected throughout the study period between 15:00 and 18:00 h. Each individual was herded into a barrier net (4 mm mesh size) placed around the territory. Fish were captured with a hand net and quickly placed into a hermetically sealed plastic bag. A small amount of clove oil, a natural anaesthetic, was sprayed into the bag causing the fish to die within a few seconds, with little evidence of pain or distress. Following the method of Grutter (1995a), the fish were then were placed individually in a $0.4 \%$ chloretone bath $(\mathrm{BDH}$ Chemicals) for $1 \mathrm{~h}$ to remove ectoparasites. The fish and its bag were then rinsed thoroughly with a wash bottle, and the entire surface of the fish, including gills and buccal cavity, was scraped gently with the nozzle of the bottle. After this procedure, 25 of the fish were scanned under a binocular microscope, which confirmed that all ectoparasites had been removed. All liquids were filtered using plankton netting $(100 \mu \mathrm{m}$ mesh size), and from the filter ectoparasites were transferred into a Petri dish for identification using a binocular microscope. Each damselfish was sexed, and standard length was measured to the nearest $\mathrm{mm}$.

Habitat assessment. Substratum cover on each reef was estimated using a transect line marked every $10 \mathrm{~cm}$. Under each point, substratum type (rock, rubble, sand, dead coral, live coral) and the type of live cover (i.e. bare, live coral, sponge, turf, macroalgae, soft coral) overlaying the various substratum types were recorded. Substratum cover and live cover were then expressed as a proportion of total points, each adding up to $100 \%$. Cleaning gobies are usually found 
on a limited number of hard coral species (i.e. Siderastrea siderea, Montastrea annularis, M. cavernosa, Agaricia agaricites, Colpophylia natans, Diploria labyrinthiformis, D. strigosa, and Porites astreoides). The coral species that were known never to support cleaning gobies (e.g. branching species such as Porites porites and Madracis madracis, and fire coral Millepora spp.) were omitted from the habitat analysis.

Statistical analyses. There was no significant difference among data collected from reefs sampled on each island. Therefore, data were pooled within island and each island was considered as a single data point in all inter-island comparisons. A principal component analysis (PCA) reduced the large numbers of intercorrelated habitat variables into 1 principal component for each reef, which was then used to investigate habitat correlates of cleaning goby abundance and client ectoparasite loads. For other analyses, we used nonparametric statistics when the data did not meet the

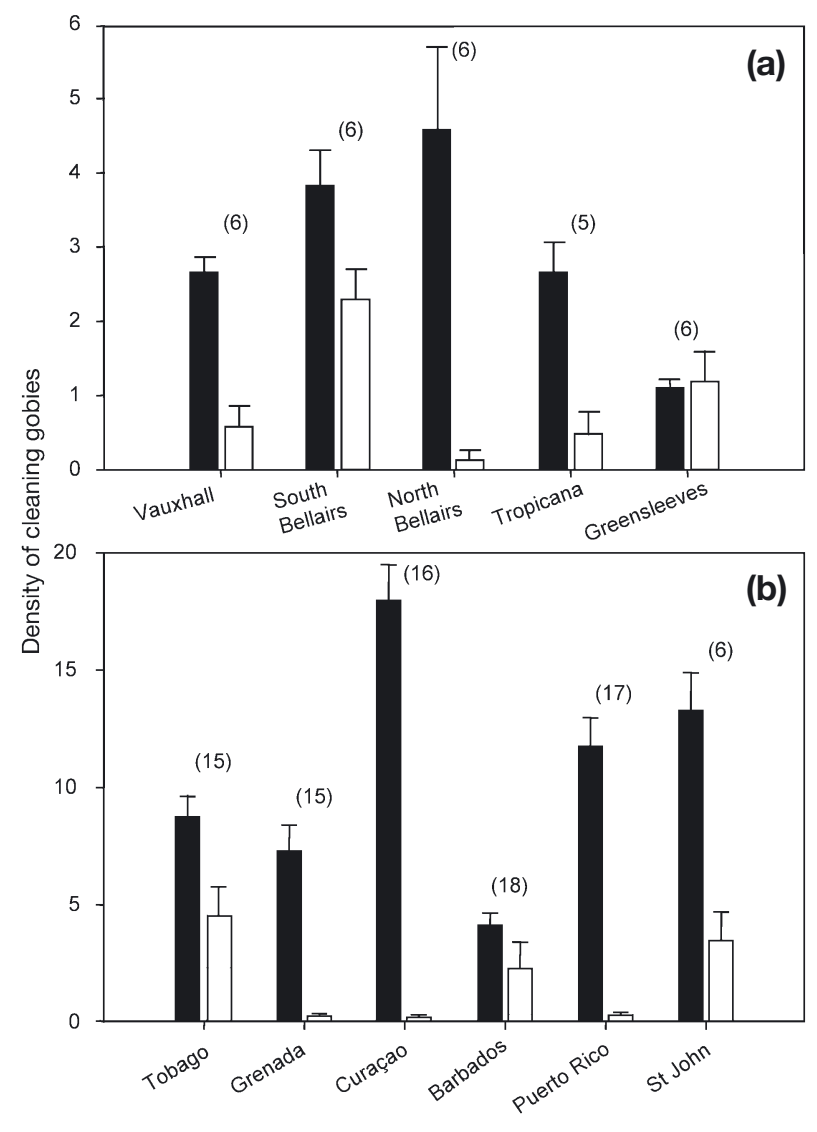

Fig. 1. Mean density (number per $40 \mathrm{~m}^{2}+1 \mathrm{SE}$ ) of cleaning gobies Elacatinus spp. found on coral (black bars) and on sponges (white bars) for (a) 5 reefs in Barbados, and (b) 6 Caribbean islands. Sample sizes (i.e. number of $10 \mathrm{~m}$ transects from which density estimates were derived) are given in parentheses. Reefs and islands are arranged from southernmost (left) to northernmost (right) assumptions of parametric testing. We also used a sequential Bonferroni p-value correction to avoid the risk of Type I error resulting from multiple tests of non-independent measures (Rice 1989). No significant results were overturned.

\section{RESULTS}

\section{Cleaning-goby and client densities}

There was significant variation in total cleaninggoby density among reefs in Barbados (ANOVA, $\left.F_{4,24}=34.3, \mathrm{p}<0.001\right)$, with the highest total densities found on North Bellairs and South Bellairs. The density of coral- and sponge-dwelling gobies, when considered separately, also varied among Barbadian reefs (ANOVA, coral-dwelling gobies: $F_{4,24}=47.8$, p $<0.001$; sponge-dwelling gobies: $F_{4,24}=5.2, p=0.004 ;$ Fig. 1a). There were significant differences in density of all cleaning gobies (ANOVA, $F_{5,12}=90.0, \mathrm{p}<0.001$ ), coraldwelling gobies $\left(\right.$ ANOVA, $F_{5,12}=198.0, p<0.001$; Fig. $1 b$ ) and sponge-dwelling gobies (ANOVA, $F_{5,12}=$ 76.0, p < 0.001; Fig. 1b) across islands. Cleaning-goby population structure, measured as the proportions of adults, sub-adults and juveniles, was similar across Barbadian reefs (Fisher's exact test, $r^{2}=7.5, \mathrm{df}=8, \mathrm{p}=$ 0.48 ) and across islands (Fisher's exact test, $r^{2}=7.5$, $\mathrm{df}=10, \mathrm{p}=0.54)$.

In Barbados, the density of coral-dwelling cleaning gobies was correlated with total client density $\left(r_{\mathrm{s}}=1.0\right.$, $\mathrm{n}=5, \mathrm{p}<0.001$; Fig. 2a). This was also true for the inter-island comparison $\left(\mathrm{r}_{\mathrm{s}}=0.88, \mathrm{n}=6, \mathrm{p}=0.02\right.$; Fig. 3a). However, the density of sponge-dwelling gobies, which clean very little, was not correlated with total client density in Barbados $\left(\mathrm{r}_{\mathrm{s}}=0.5, \mathrm{n}=5, \mathrm{p}=0.39\right)$ or across islands $\left(\mathrm{r}_{\mathrm{s}}=-0.67, \mathrm{n}=6, \mathrm{p}=0.17\right)$.

\section{Gnathiid larval emergence rates}

In Barbados, the total density of cleaning gobies on each reef tended to increase with the rate of emergence of gnathiid isopod larvae $(\mathrm{r}=0.86, \mathrm{n}=5, \mathrm{p}=$ 0.06). A similar and significant relationship was observed across islands $(\mathrm{r}=0.82, \mathrm{n}=6, \mathrm{p}=0.04)$. However, when cleaning gobies on different substrata were considered separately, we found that the density of coral-dwelling cleaning gobies increased significantly with the rate of gnathiid emergence in Barbados $(\mathrm{r}=$ 0.92, $\mathrm{n}=5, \mathrm{p}=0.04$; Fig. 2b) and across islands ( $\mathrm{r}=0.82, \mathrm{n}=6, \mathrm{p}=0.04$; Fig. $3 \mathrm{~b}$ ), but this was not the case for sponge-dwelling cleaning gobies (Barbados: $\mathrm{r}=0.66, \mathrm{n}=5, \mathrm{p}=0.92 ;$ among islands: $\mathrm{r}=-0.16, \mathrm{n}=6$, $\mathrm{p}=0.76)$. 

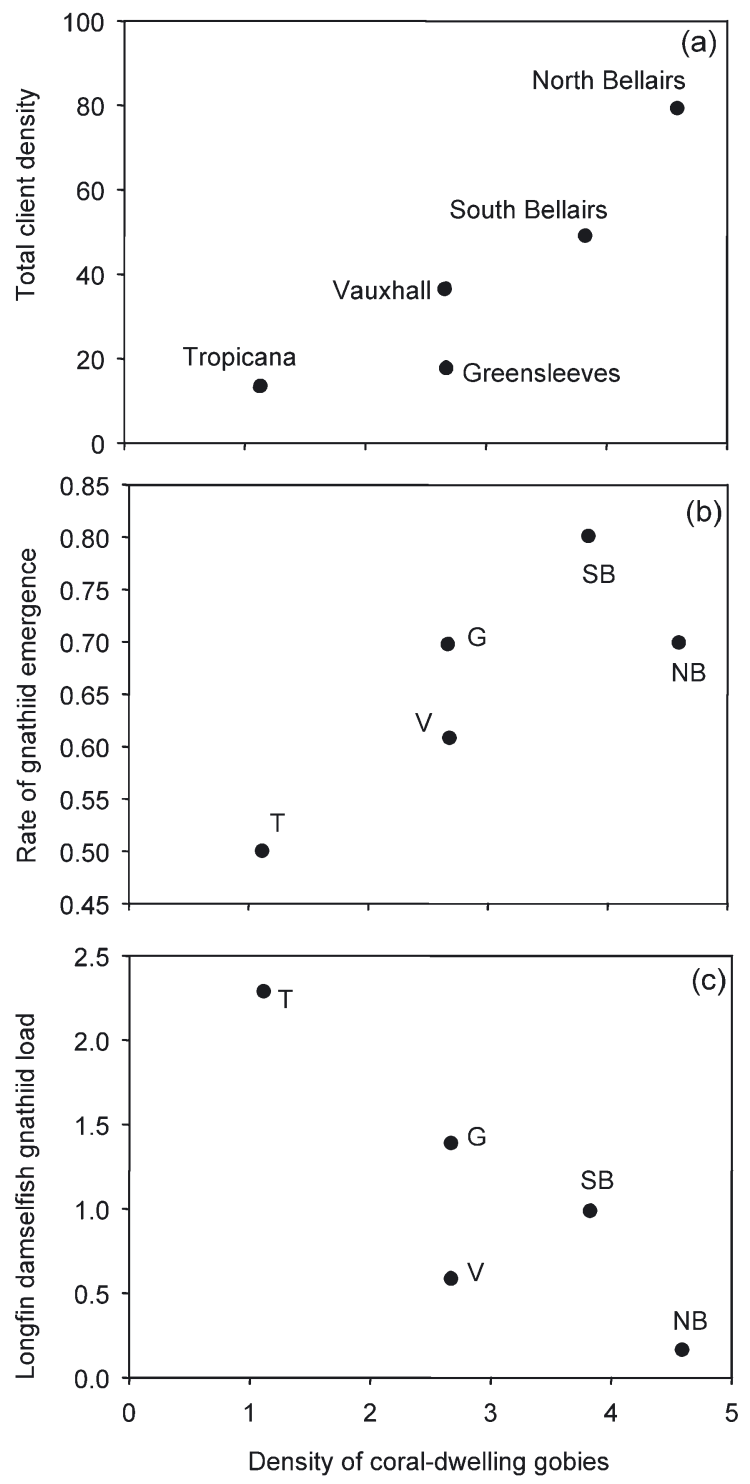

Fig. 2. (a) Total client density (no. clients per $40 \mathrm{~m}^{2}$ ), (b) rate of gnathiid larval emergence (no. gnathiids $\mathrm{m}^{-2}$ per $24 \mathrm{~h}$ ), and (c) longfin damselfish Stegastes diencaeus ectoparasite load (no. gnathiids per damselfish) in relation to the density of coral-dwelling cleaning gobies Elacatinus spp. (no. gobies per $40 \mathrm{~m}^{2}$ ) for 5 reefs in Barbados. Letters in (b) and (c) correspond to the first letter of the locations shown in (a)

\section{Client ectoparasite loads and overall ectoparasite availability}

In Barbados, there were significant differences in gnathiid loads on longfin damselfish among reefs (Kruskal-Wallis test, $H_{4}=13.5, \mathrm{p}=0.01$ ). Damselfish on Tropicana reef had significantly more gnathiids than those on North Bellairs, South Bellairs, Greensleeves or Vauxhall reefs (Mann-Whitney $U$-tests, $U<7.5$, $\left.\mathrm{n}_{1}=5, \mathrm{n}_{2}=5, \mathrm{p}<0.03\right)$. Damselfish gnathiid loads were not correlated with gnathiid emergence rates across Barbadian reefs $\left(\mathrm{r}_{\mathrm{s}}=-0.77, \mathrm{n}=5, \mathrm{p}=0.19\right)$.

The density of coral-dwelling cleaning gobies on Barbadian reefs tended to decrease with increasing numbers of gnathiids on longfin damselfish $\left(\mathrm{r}_{\mathrm{s}}=-0.82\right.$, $\mathrm{n}=5, \mathrm{p}=0.09$; Fig. 2c). By contrast, sponge-dwelling goby density did not covary with longfin ectoparasite load $\left(r_{s}=0.10, n=5, p=0.87\right)$. There was no correlation between cleaning goby density and total gnathiid availability (i.e. total client density $\times$ average gnathiid load for longfish damselfish), either for coral-dwelling $\left(\mathrm{r}_{\mathrm{s}}=-0.10, \mathrm{n}=5, \mathrm{p}=0.87\right)$ or for sponge-dwelling gobies $\left(\mathrm{r}_{\mathrm{s}}=-0.30, \mathrm{n}=5, \mathrm{p}=0.62\right)$.
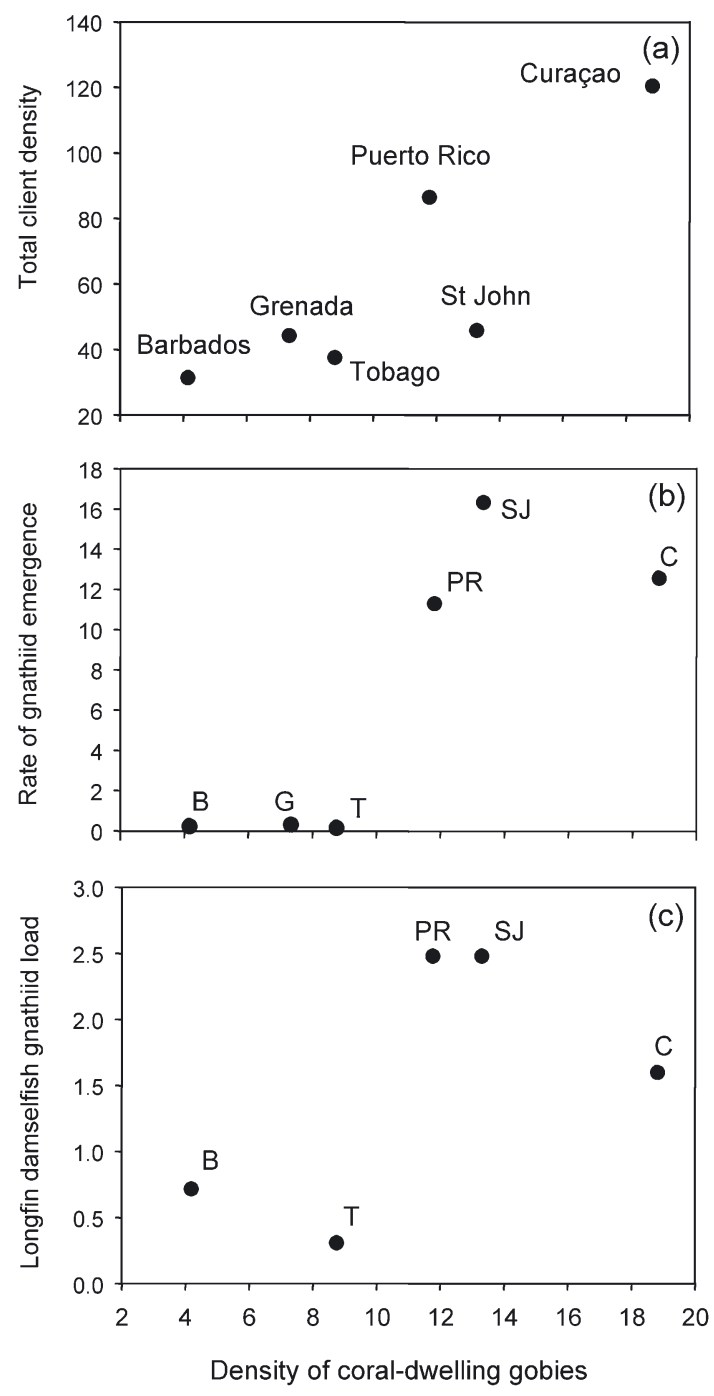

Fig. 3. (a) Total client density (no. clients per $40 \mathrm{~m}^{2}$ ), (b) rate of gnathiid larval emergence (no. gnathiids $\mathrm{m}^{-2}$ per $24 \mathrm{~h}$ ), and (c) longfin damselfish Stegastes diencaeus ectoparasite load (no. gnathiids per damselfish) in relation to the density of coral-dwelling cleaning gobies Elacatinus spp. (no. gobies per $40 \mathrm{~m}^{2}$ ) for 6 Caribbean islands. Letters in (b) and (c) correspond to the first letter of the locations shown in (a) 
Table 1. Percentage cover of various substrata on study reefs. Means \pm SD are given. Sample sizes (i.e. number of $10 \mathrm{~m}$ transects from which cover estimates were derived) are given in parentheses

\begin{tabular}{|c|c|c|c|c|c|c|}
\hline & $\begin{array}{c}\text { Tobago } \\
\text { (15) }\end{array}$ & $\begin{array}{l}\text { Grenada } \\
\text { (17) }\end{array}$ & $\begin{array}{c}\text { Curaçao } \\
\text { (18) }\end{array}$ & $\begin{array}{l}\text { Barbados } \\
\quad(18)\end{array}$ & $\begin{array}{l}\text { Puerto Rico } \\
\text { (20) }\end{array}$ & $\begin{array}{l}\text { St John } \\
\quad(6)\end{array}$ \\
\hline \multicolumn{7}{|c|}{ Substratum type } \\
\hline Rock & $39.6 \pm 3.2$ & $42.4 \pm 2.0$ & $45.0 \pm 13.4$ & $57.1 \pm 14.0$ & $28.5 \pm 1.2$ & $51.3 \pm 9.1$ \\
\hline Rubble & $3.3 \pm 0.4$ & $2.3 \pm 0.4$ & $7.2 \pm 1.2$ & $7.5 \pm 5.0$ & $6.4 \pm 0.8$ & $4.3 \pm 0.6$ \\
\hline Sand & $10.5 \pm 3.5$ & $18.0 \pm 5.6$ & $26.1 \pm 5.6$ & $11.4 \pm 7.2$ & $34.7 \pm 2.4$ & $1.2 \pm 0.9$ \\
\hline Dead coral & $8.7 \pm 2.4$ & $5.5 \pm 1.4$ & $1.7 \pm 1.8$ & $1.9 \pm 1.6$ & $19.2 \pm 3.4$ & $31.3 \pm 5.6$ \\
\hline Live coral & $37.9 \pm 9.7$ & $31.8 \pm 10.1$ & $20.0 \pm 5.6$ & $22.2 \pm 7.6$ & $11.6 \pm 3.4$ & $12.5 \pm 3.9$ \\
\hline \multicolumn{7}{|c|}{ Live cover type } \\
\hline Bare & $3.5 \pm 1.3$ & $10.0 \pm 2.3$ & $18.3 \pm 4.5$ & $8.5 \pm 1.2$ & $2.3 \pm 1.3$ & $16.6 \pm 4.5$ \\
\hline Coral & $37.9 \pm 9.7$ & $31.8 \pm 10.1$ & $20.0 \pm 5.6$ & $22.2 \pm 7.6$ & $11.6 \pm 3.4$ & $12.5 \pm 3.9$ \\
\hline Sponge & $2.8 \pm 0.3$ & $0.3 \pm 0.1$ & $4.3 \pm 2.3$ & $1.0 \pm 1.0$ & $3.8 \pm 0.2$ & $3.5 \pm 0.2$ \\
\hline Turf algae & $50.4 \pm 12.2$ & $33.5 \pm 6.5$ & $52.9 \pm 6.9$ & $58.9 \pm 15.7$ & $30.7 \pm 2.4$ & $59.7 \pm 8.3$ \\
\hline Macroalgae & $5.8 \pm 1.2$ & $24.1 \pm 4.3$ & $2.4 \pm 0.5$ & $7.0 \pm 3.7$ & $13.4 \pm 3.4$ & $5.3 \pm 2.3$ \\
\hline Soft coral & $0.5 \pm 0.1$ & $0.3 \pm 0.1$ & $2.1 \pm 0.3$ & $2.4 \pm 1.2$ & $38.2 \pm 3.4$ & $2.4 \pm 0.2$ \\
\hline
\end{tabular}

On a larger geographic scale, overall gnathiid loads varied significantly among islands (Kruskal-Wallis test, $H_{5}=26.4, \mathrm{p}<0.001$ ), with damselfish in Tobago having the fewest ectoparasites (mean \pm SD: $0.22 \pm 0.43, \mathrm{n}=18$ ) and those from Puerto Rico the most (mean \pm SD: $1.63 \pm$ $1.46, \mathrm{n}=20$ ). Across islands, mean damselfish ectoparasite loads increased with increasing rate of emergence of gnathiids $\left(\mathrm{r}_{\mathrm{s}}=0.90, \mathrm{n}=5, \mathrm{p}=0.04\right)$. However, there was no correlation between cleaning goby density and longfin ectoparasite load, either for coral-dwelling gobies $\left(\mathrm{r}_{\mathrm{s}}=0.60, \mathrm{n}=5, \mathrm{p}=0.29\right.$; Fig. $\left.3 \mathrm{c}\right)$ or spongedwelling gobies $\left(r_{s}=-0.30, n=5, p=0.62\right)$. There was no correlation between goby density and total gnathiid availability for coral-dwelling $\left(r_{s}=0.71, n=6, p=0.11\right)$ or for sponge-dwelling gobies $\left(r_{s}=-0.26, n=6, p=0.62\right)$.

\section{Distribution of cleaning gobies in relation to habitat characteristics}

Habitat characteristics differed among islands (Table 1). We found no correlation between gnathiid emergence rates and general habitat characteristics among reefs in Barbados (all $\mathrm{r}<0.84, \mathrm{n}=5$, $\mathrm{p}>0.08$ ). Gnathiid emergence rate was also not related to the percent cover of any individual hard-coral species (all $\mathrm{r}<$ $0.78, \mathrm{n}=5, \mathrm{p}>0.12$ ). The first principal component extracted explained $50.7 \%$ of the variance in habitat characteristics, and represented a gradient of increasing live hard-coral cover and decreasing rock and turf algae. Gnathiid emergence rates were not correlated with this habitat factor $(\mathrm{r}=-0.15, \mathrm{n}=5, \mathrm{p}=0.81)$. We also found no correlation between ectoparasite emergence rates and habitat characteristics among islands (all $\mathrm{r}<0.58, \mathrm{n}=6$, $\mathrm{p}>0.22$ ), for individual coral species (all $\mathrm{r}<0.31, \mathrm{n}=6$, $\mathrm{p}>0.54)$ or when reef characteristics were collapsed using a PCA factor analysis $(r=0.25, n=6, p=0.62)$. In this case, the first PCA factor explained $42.0 \%$ of the variance in habitat characteristics among islands, and represented increasing hard and soft coral cover and decreasing turf and macroalgae cover.

There was no correlation between damselfish ectoparasite load and habitat characteristics collapsed into a PCA factor in Barbados $\left(\mathrm{r}_{\mathrm{s}}=0.20, \mathrm{n}=5, \mathrm{p}=0.75\right)$, or across islands $\left(\mathrm{r}_{\mathrm{s}}=-0.40, \mathrm{n}=5, \mathrm{p}=0.51\right)$. Similarly, with habitat variables collapsed into a PCA factor, we found no correlation between client density and habitat characteristics on Barbados $\left(\mathrm{r}_{\mathrm{s}}=0.28, \mathrm{n}=5, \mathrm{p}=\right.$ $0.66)$ or across islands $\left(r_{s}=-0.43, n=6, p=0.39\right)$.

On Barbados, the number of coral-dwelling cleaning gobies was not correlated with live coral cover $(\mathrm{r}=$ $-0.72, \mathrm{n}=5, \mathrm{p}=0.17$ ) or with the percent cover of individual coral species (all $\mathrm{r}<0.80, \mathrm{n}=5, \mathrm{p}>0.11$ ). This was also the case between islands for live coral cover ( $\mathrm{r}=-0.01, \mathrm{n}=6, \mathrm{p}=0.98)$ and for cover of the commonest individual coral species $(\mathrm{r}=-0.01, \mathrm{n}=6, \mathrm{p}=$ 0.98). There were also no correlations between the number of coral-dwelling cleaning gobies and any other habitat variables for Barbados (all $\mathrm{r}<0.72, \mathrm{n}=5$, $\mathrm{p}>0.17$ ) or across islands (all $\mathrm{r}<0.62, \mathrm{n}=6, \mathrm{p}>0.34$ ). The number of sponge-dwelling gobies was, however, correlated with the percentage cover of sponge Xestospongia muta in Barbados ( $\mathrm{r}=0.97, \mathrm{n}=6, \mathrm{p}<$ $0.001)$ and across islands $(\mathrm{r}=0.93, \mathrm{n}=5, \mathrm{p}<0.001)$.

\section{DISCUSSION}

The distribution of obligate cleaner fish across Caribbean reefs appears to be correlated with ectoparasite availability. As we had initially predicted, coraldwelling cleaning gobies, which are active cleaners (Whiteman \& Côté 2002), were more abundant in areas where the rate of emergence from the benthos of their 
preferred prey, i.e. parasitic gnathiid isopod larvae (Arnal \& Côté 2000), was high and where clients were more numerous (see also Arnal et al. 1999). By contrast, high densities of sponge-dwelling cleaning gobies, which feed mainly on benthic invertebrates within sponge tissue (Whiteman \& Côté 2002), were not associated with ectoparasite emergence or client numbers.

Contrary to one of our predictions, we found that higher densities of coral-dwelling cleaning gobies tended to coincide with lower gnathiid loads on their clients, at least on a small, island-wide scale (see also Sikkel et al. 2000). Our prediction was based on the premise that cleaner fish are known to approach and inspect preferentially clients with high ectoparasite loads (Gorlick 1984, Grutter 1995b). However, cleaners have also been shown to reduce significantly the number of ectoparasites on their clients (Grutter 1999, Cheney \& Côté 2001, in press, Grutter \& Lester 2002). Our results may therefore simply reflect the outcome of cleaning goby activity, which is more marked on reefs where cleaning gobies are more numerous. This effect may also have contributed to the absence of a relationship between cleaner fish density and total ectoparasite availability, which we estimated as the product of total client density and damselfish ectoparasite load.

We had predicted higher densities of coral-dwelling cleaning gobies in habitats associated with high rates of gnathiid emergence and/or high client ectoparasite loads. Surprisingly, gnathiid emergence rate was not related to any habitat characteristic measured. Gnathiid larvae are known to emerge in larger numbers from coral than from sandy substrata (Sikkel et al. in press, K. L. Cheney unpubl. data). Reefs with relatively higher coral cover should therefore be expected to produce more gnathiids, but this was not the case. One possible explanation is that the assessment of habitat characteristics carried out on the whole-reef scale is not an exact reflection of the specific substratum over which individual emergence traps were placed. Habitat assessment under emergence traps may have revealed a relationship between gnathiid emergence and small-scale habitat type.

We also found no habitat correlates of longfin damselfish ectoparasite load. Such correlates have usually been investigated on a coarser scale (e.g. among reef zones: Yeo \& Spieler 1980, Grutter 1998) than we have used here. Sikkel et al. (2000), for example, found that yellowtail damselfish Microspathodon chrysurus on the seaward edge of the North Bellairs reef in Barbados harboured fewer ectoparasites than those closer to shore. The deeper spur-and-groove zone on this reef has higher live cover than the backreef area (K. L. Cheney pers. obs.), thus suggesting a link between coral cover and fish ectoparasite load. However, the distribution of yellowtail damselfish is also sex-biased, with males found further from shore (Sikkel et al. 2000). Gender could therefore influence ectoparasite load more than habitat features.

Given that neither gnathiid emergence rate, client ectoparasite load nor client density was related to specific habitat types, it was perhaps not surprising to find that inter-reef and inter-island variation in the density of coral-dwelling gobies was not related to habitat. By contrast, the density of sponge-dwelling cleaning gobies, which was not associated with higher ectoparasite emergence or client density, was closely linked to the abundance of sponge. Whiteman \& Côté (2002) have shown that sponge-dwelling cleaning gobies feed mainly on polychaete worms found in sponge tissues, and therefore rely very little on ectoparasites gleaned through cleaning activity.

The interrelationships between cleaning goby density and measures of ectoparasite availability appear to be similar on small and larger geographical scales, with one possible exception. While the density of coral-dwelling gobies tended to be inversely related to gnathiid intensity on damselfish within Barbados, there was no hint of such a relationship across islands. As previously discussed, the intra-island pattern may be explained as the result of cleaning goby foraging on clients. Although this local-scale effect is likely to be recurrent on each of the islands, collapsing each relationship into a single mean goby-density and client-gnathiid load could generate a variety of inter-island relationships. Thus the large-scale pattern need not mirror the smaller scale one.

In conclusion, we show for the first time a link between cleaner fish abundance and ectoparasite availability, which holds on both small and large scales. Could ectoparasite availability be a consequence rather than a cause of cleaning goby abundance? Under this scenario, cleaning gobies would choose to settle on a reef for reasons unconnected to food resources, and their abundance would then determine both client density and rates of ectoparasite emergence. This is unlikely for 2 reasons. First, there is little evidence that cleaning goby recruitment is linked to factors unrelated to foraging. Such factors could include the presence of predators (Steele et al. 1998) and conspecifics (Macpherson \& Zika 1999, Schmitt \& Holbrook 2002). The latter could be particularly important for coral-dwelling cleaning gobies, since they live in permanent monogamous pairs (Whiteman \& Côté 2003), and living in higher density populations would enhance their likelihood of finding first mates, or new mates if widowed. However, the presence of conspecifics does not affect cleaning goby recruitment (Wilson \& Osenberg 2002, E. Whiteman pers. comm.). The only known correlate of cleaning goby recruitment is coral head size, which is linked to the presence of active cleaning stations (Wilson \& Osenberg 2002). Second, recent observational and experimental evidence suggests that cleaning gobies do not determine local 
client abundance, at least not for territorial species (Whiteman et al. 2002, Cheney \& Côté 2003), which would be necessary under the alternative causal scenario. It thus seems more likely that the abundance of clients and, more specifically, of ectoparasites, determines cleaning goby numbers. Whether this relationship is mediated through differential recruitment or differential survival of cleaning gobies in parasite-rich and -poor areas remains to be determined.

Acknowledgements. For logistical support, we thank the staff at Bellairs Research Institute, Barbados, Isla Magueyes Marine Laboratory, Puerto Rico, CARMABI Institute, Curaçao and Virgin Islands Environmental Resource Station, University of the Virgin Islands. We would especially like to thank P. C. Sikkel for help in Puerto Rico, M. Harvey in Tobago, L. Robertson in Grenada, and P. Frade and R. Jacinto in Curaçao. K.L.C. was supported by a Biotechnology and Biological Sciences Research Council PhD studentship of the UK and we thank the University of East Anglia and the John and Pamela Salter Charitable Trust for financial support.

\section{LITERATURE CITED}

Arnal C, Côté IM (2000) Diet of broadstripe cleaning gobies on a Barbadian reef. J Fish Biol 57:1075-1082

Arnal C, Morand S, Kulbicki M (1999) Patterns of cleaner wrasse density among three regions of the Pacific. Mar Ecol Prog Ser 177:213-220

Bshary R (2003) The cleaner wrasse, Labroides dimidiatus, is a key organism for reef fish diversity at Ras Mohammed National Park, Egypt. J Anim Ecol 72:169-176

Cadoret L, Legendre P, Adjeroud M, Galzin R (1995) Spatial distribution of Chaetodontidae in different coral-reef sectors of Moorea island in French Polynesia. Ecoscience 2:129-140

Cheney KL, Côté IM (2001) Are Caribbean cleaning symbioses mutualistic? Costs and benefits of visiting cleaning stations to longfin damselfish. Anim Behav 62:927-933

Cheney KL, Côté IM (2003) Habitat choice in adult longfin damselfish: territory characteristics and relocation times. J Exp Mar Biol Ecol 287:1-12

Cheney KL, Côté IM (in press) The ultimate effect of being cleaned: does ectoparasite removal have reproductive consequences for damselfish clients? Behav Ecol

Côté IM (2000) Evolution and ecology of cleaning symbioses in the sea. Ocean Mar Biol Annu Rev 38:311-355

Davies AJ, Eiras JC, Austin RTE (1994) Investigations into the transmission of Haemogregarina bigemina Laveran and Mesnil, 1901 (Apicomplexa, Adeleorina) between intertidal fishes in Portugal. J Fish Dis 17:283-289

Gorlick DL (1984) Preference for ectoparasite-infected host fishes by the Hawaiian cleaning wrasse, Labroides phthirophagus (Labridae). Copeia 1984:758-762

Grutter AS (1995a) Comparison of methods for sampling ectoparasites from coral reef fishes. Mar Freshw Res 46: 897-903

Grutter AS (1995b) The relationship between cleaning rates and ectoparasite loads in coral reef fishes. Mar Ecol Prog Ser 118:51-58

Grutter AS (1996) Parasite removal rates by the cleaner wrasse Labroides dimidiatus. Mar Ecol Prog Ser 130:61-70

Grutter AS (1997) Spatiotemporal variation and feeding selectivity in the diet of the cleaner fish Labroides dimidiatus. Copeia 1997:346-355
Grutter AS (1998) Habitat-related differences in the abundance of parasites from a coral reef fish: an indication of the movement patterns of Hemigymnus melapterus. J Fish Biol 53:49-57

Grutter AS (1999) Cleaner fish really do clean. Nature 398: $672-673$

Grutter AS (2002) Cleaning symbioses from the parasite's perspective. Parasitology 124:S65-S81

Grutter AS, Lester RJG (2002) Cleaner fish Labroides dimidiatus reduce 'temporary' parasitic corallanid isopods on the coral reef fish Hemigymnus melapterus. Mar Ecol Prog Ser 234:247-255

Grutter AS, Murphy JM, Choat JH (2003) Cleaner fish drives local fish diversity on coral reefs. Curr Biol 13:64-67

Honma Y, Chiba A (1991) Pathological changes in the branchial chamber wall of stingrays, Dasyatis spp. associated with the presence of juvenile gnathiids (Isopoda, Crustacea). Fish Pathol 26:9-16

Jacoby CA, Greenwood JG (1988) Spatial, temporal, and behavioural patterns in emergence of zooplankton in the lagoon of Heron Reef, Great Barrier Reef, Australia. Mar Biol 97:309-328

Khalaf MA, Kochzius M (2002) Changes in trophic community structure of shore fishes at an industrial site in the Gulf of Aqaba, Red Sea. Mar Ecol Prog Ser 239:287-299, Erratum 241:306-307

Macpherson E, Zika U (1999) Temporal and spatial variability of settlement success and recruitment level in three blennioid fishes in northwestern Mediterranean. Mar Ecol Prog Ser 182:269-282

Molloy PP, Côté IM (2003) Temporal variation in cleanerfish and client behaviour: does it reflect ectoparasite availability? Ethology 109:487-499

Paperna I, Por FD (1977) Preliminary data on the Gnathiidae (Isopoda) of the northern Red Sea, the Bitter Lakes and the eastern Mediterranean and the biology of Gnathia piscivora n. sp. Rapp Com Méd 24:195-197

Rice WR (1989) Analyzing tables of statistical tests. Evolution 43:223-225

Schmitt R, Holbrook S (2002) Correlates of spatial variation in settlement of two tropical damselfishes. Mar Freshw Res 53:329-337

Sikkel PC, Fuller CA, Hunte W (2000) Habitat/sex differences in time at cleaning stations and ectoparasite loads in a Caribbean reef fish. Mar Ecol Prog Ser 193:191-199

Sikkel PC, Cheney KL, Côté IM (in press) In situ evidence for ectoparasites as a proximate cause of cleaning interactions in reef fish. Anim Behav

Steele MA, Forrester GE, Almany GR (1998) Influences of predators and conspecifics on recruitment of a tropical and a temperate reef fish. Mar Ecol Prog Ser 172:115-125

Whiteman EA, Côté IM (2002) Cleaning activity of two Caribbean cleaning gobies: intra- and interspecific comparisons. J Fish Biol 60:1443-1458

Whiteman EA, Côté IM (2003) Social monogamy in the cleaning goby Elactinus evelynae: ecological constraints or net benefits? Anim Behav 66:281-291

Whiteman EA, Côté IM, Reynolds JD (2002) Do cleaning stations affect the distribution of territorial reef fishes? Coral Reefs 21:245-251

Wilson J, Osenberg CW (2002) Experimental and observational patterns of density-dependent settlement and survival in the marine fish Gobiosoma. Oecologia 130:205-215

Yeo SE, Spieler RE (1980) Habitat effects on the occurrence of parasites inhabiting the sergeant major, Abudefduf saxatilis (Linneaus), with a list of parasites of Caribbean damselfishes. Bull Mar Sci 30:313-324 